\title{
Economic Analysis of Onion Production Along River Komadugu Area of Yobe State,Nigeria.
}

\author{
${ }^{1}$ Grema, I. J., ${ }^{2}$ Gashua, A.G. \\ ${ }^{1,2}$ Department of Agricultural Technology, Yobe State College of Agriculture, Gujba.
}

\begin{abstract}
This study focus on the economic analysis of onion production along river Komadugu area of Yobe State, Nigeria. A multi stage sampling technique was employed for collecting primary data from a sample of one hundred and twenty (120) onion farmers in the study area. Analytical tools used were; descriptive statistics, farm budgeting models, and inferential statistics. Findings indicated that most of the out growers are male and Majority were middle age (35-44 years) and have had substantial experience in onion production.

The net farm income analysis showed that onion production was profitable $(N 98,134 / h a)$. The production function analysis revealed that a unit increase in farm size, hired labour, seeds, herbicide, fertilizer and insecticide provide an extra yield of 222.60, 100.90, 100.99,15.00, 70.00 and $12.50 \mathrm{~kg} / \mathrm{ha}$ respectively. The analysis also indicated that farm size has the highest MVP (N14, 469.00). The study also found that land size, labour, seed and fertilizer were over utilized for onion production with efficiency ratio greater than one (2.41, 9.37, 6.56 and 2.21) while, insecticide and herbicide were under utilized for onion production with efficiency ratio of less than one (0.77 and 0.54).Problems associated with high cost of production inputs, lack of adequate storage facilities, limited access to improved seeds, high cost of transport, fluctuation of market price and lack of sufficient capital among others were some of the problems identified as confronting onion farmers in the study area. Policies to ensure adequate and sustainable supply of basic onion production inputs, improve access to good transportation networks, improve market structures in the study area were preferred as policy recommendations.
\end{abstract}

Key words: Onion, Out-growers, Marginal value product

\section{Introduction}

Onion (Allium cepa L) has about 500 spp of herbs, occurring through out the northern hemisphere, with the greatest number in the USSR (Wright, 1992). As an important food, the immature and mature bulbs are eaten raw or they may be cooked and eaten as vegetable. Onions, compared with other fresh vegetables, are relatively high in food value, intermediate in protein content and are rich in calcium and riboflavin (Purse glove et-al, 2000)

Onion is not known with certainty as a wild plant. It is believed to have originated in an area which includes Iran, West Pakistan and the mountainous countries to the North (Purse glove et-al, 2000).

Nigeria like any other developing country is faced with rapid population growth and expanding urban population which increase demand on agricultural production (Nasiru, 2000) In Nigerian economy, Onion has become an important cash crop cultivated in virtually all the irrigable land of all the agro- ecological zones from North-east to the North-west(NEAZDP,1999).

The relatively poor performance of onion production in the country is constrained by a number of factors such as soil disease, climate and weeds. Among these factors, weed control is most important as it has been reported to be responsible for between 70 and $89 \%$ losses in the bulb yield (Warreb, 1975; William, 1975).The traditional hoe-weeding the most prevalent method of controlling weeds in the crop is expensive, labour intensive and time consuming. It is in the light of these constraints to hoe-weeding that the use of herbicides has been tried and observed to reduce labour requirement and its attendants costs, facilities, efficient weed control and also increase profitability in onion production (peter, 1996).

Onions are highly perishables, since they are extremely sensitive to heat and humidity. They require much care from harvest to transport, with special attention for packing and storage. The poor state of road coupled with administrative wrangling, slow down the progress of delivery trucks, impairing the quality of merchandise and adding to costs.

The production of Onion in Nigeria has been on the increase According to Ali and Chaudbury (1990), This indicates the availability of raw materials and prospect of not running into short supply Production analysis on Onion would help to achieve fully the comparative advantage the study area has and the propensity to transformed the nation's economy, generate employment and reduce poverty. The information generated through this study is also expected to support policy makers on issues associated with the decisions making on investments and the zeal to add to the little available knowledge of Onion production along River Komadugu Area in Yobe State. 
Ogunjobi (1999) stated that productivity measurement is important because it is a success indicator and measure by which production units are monitored and evaluated. It is only by measuring productivity and separating its effects from the effect of the environment can one explore hypothesis concerning the Source of marketing differential.

With specific reference to onion production, a pre-requisite for enhanced marketing is the identification of those factors which prevail at the farm and market level and which affect the production of onion. Such an investigation is important for the following reasons:

Firstly, there is a linkage between food related issues and economic development in low income countries. Therefore, increasing resource productivity in onion production stands out among the requirements for social equity in terms of both poverty relief and building up of economic activities. In the process, desirable changes take place in the pattern of economic development especially in terms of enlarging domestic market and increasing the relatives' weight of agricultural activities (Amaza, 2000).

Secondly, farmers especially small scale farmers constitute a majority of the rural poor in most developing countries including Nigeria. This study therefore becomes imperative as it reveals the potentials and constraints of farmers as well as factors at farm level that affect onion farmer's productivity and profitability in the study area as well as provide policy measures that will boost the production of onion along River Komadugu area of Yobe State, Nigeria.

Finally, it is also hoped that by attempting to analyze the production of Onion in the study area, that information obtained would be of great relevance to all actors and researchers for academic purposes.

\section{Methodology}

The study was conducted along River Komadugu Area of Yobe State. This study has considered the Local Government Areas (LGAs) along the hydrological position of River Komadugu Yobe as one cluster, which consist of; Bade, Bursari, Geidam and Jakusko LGAs.

\section{Sampling Techniques}

For the purpose of this study, a multistage sampling procedure was adopted. Jakusko, Bade, Bursari and Geidam LGAs of Yobe State were purposively selected based on their hydrological position relative to the River Komadugu Yobe, and importance of the LGAs in the production of onion.

From each local government two important villages, Azbak and Usur (Bade LGA), Jawa and Gadine (Bursari LGA), Balle and Shuwari (Geidam LGA), Kurkushe and Zabudum (Jakusko LGA) were purposively selected primarily due to the high onion production activities and secondly, the preponderance of onion farmers, which is obviously related to the total onion production in the areas. From each of the 8 villages selected for this study, a list of relevant Farmers were obtained from the Fadama Farmers Associations (FFA) officials. 15 onion producers were randomly selected from the list obtained from FFA officials. Therefore a total of 120 Onion farmers from the list of 619 onion farmers were sampled from the 8 villages, however, only 114 questionnaires for onion farmers were appropriately filled and retrieved.

\section{Data collection}

Both Primary and secondary data were used in the study. Primary data was obtained from onion Farmers using structured questionnaire to a random selection of onion farmers in the study area. The information covered the socio-economic characteristics of onion farmers, their production inputs, costs of production and returns as well as problems associated with onion production among the onion farmers in the study Area.

\section{Data analysis.}

Data gathered for the study were analyzed using descriptive statistics(frequency and percentages), farm budgeting model(Net farm income) and inferential statistics(Regression analysis).

Net farm income $(\mathrm{NFI})=$ GI-TC $($ TVC + TFC $)$

'GI $=$ Gross income (value of onion produced (Naira)

$\mathrm{TC}=$ Total cost of producing Onion in (Naira)

Multiple regression models were employed for the Estimates of resource-use efficiency of the Onion farmers in the study area.

The model used is given as follows:

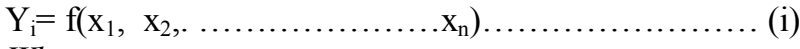

Where,

$\mathrm{Y}_{\mathrm{i}}=$ dependent variable representing the yield of onion

$\mathrm{X}_{1} \ldots \ldots \ldots \ldots \mathrm{X}_{\mathrm{n}}=$ representing the independent variables (land size, seed, labour, fertilizer, insecticide, herbicide)

The multiple regressions appear thus; 
$Y_{i}=\alpha+\beta_{1} x_{i 1}+\beta_{2} x_{i 2}+\beta_{3} x_{i 3}+\beta_{4} x_{i 4}+\beta_{5} x_{i 5}+\beta_{6} x_{i 6}+\beta_{n} x_{i n}+e_{i}$

Where,

$\mathrm{Y}_{\mathrm{i}}=$ yield of onion $(\mathrm{kg} / \mathrm{ha})$

$\mathrm{X}_{1}=$ Land size in $\mathrm{Ha}$

$\mathrm{X}_{2}=$ quantity of seeds $(\mathrm{kg} / \mathrm{ha})$

$\mathrm{X}_{3}=$ quantity of labour (man-days/ha)

$\mathrm{X}_{4}=$ quantity of fertilizer $(\mathrm{kg} / \mathrm{ha})$

$\mathrm{X}_{5}=$ quantity of insecticide (liters/ha)

$\mathrm{X}_{6}=$ quantity of herbicide (liters/ha)

$\alpha=$ constant term

$\beta_{1}-\beta_{\mathrm{n}}=$ Regression coefficient

$\mathrm{X}_{1}-\mathrm{X}_{6}=$ independent variables that were included in the model

$\mathrm{e}_{\mathrm{i}}=$ Stochastic error term for the $\mathrm{i}^{\text {th }}$ term

\section{Resource-use efficiency}

The efficiency of resource use in the production of Onion was determined by employing tools for measuring efficiency thus;

The marginal value product (MVP) of the resource used in Onion production was estimated by multiplying the marginal physical product (MPP) by the unit price of the output (Y).

That is, $\mathrm{MVP}_{\mathrm{xi}}=\mathrm{MPP}_{\mathrm{xi}}$ py

Where,

$\mathrm{MVP}_{\mathrm{xi}}=$ marginal value product of $\mathrm{i}^{\text {th }}$ input

$\mathrm{MPP}_{\mathrm{xi}}=$ marginal physical product of the $\mathrm{i}^{\text {th }}$ input

$\mathrm{Py}=$ price of unit output

The marginal value product (MVP) was divided by the cost of one unit of the (marginal factor cost) to make influence on resource-use efficiency. In order to make the relative efficiency of resource use the following ratios were computed:

$\mathrm{r}=\mathrm{MVP} / \mathrm{MFC}$

Where

$\mathrm{r}=$ efficiency ratio

MVP $=$ marginal value product

$\mathrm{MFC}=$ marginal factor cost

If $\mathrm{r}=1$, resource is efficiently used

$\mathrm{r}<1$, resource is under-utilized

$r>1$, resource is over-utilized

\section{Results And Discussion}

It shows in table 1 that majority of the farmers (41.22\%) were between the ages of 35-44 years, This is in accordance with the findings of Peter,(1996), that $42 \%$ of the respondents were within the active age of 35 44years. Followed by those between $45-54$ years $(34.21 \%$ ); while only $3.51 \%$ of the farmers were within the age of 65 and above. This survey therefore, reveals that more of the middle age groups were engaged in onion farming in the study area than the young and old age group. Which tallies with the result of Solomon,(2010), who reported that farmers at this age are strong and capable of making good production decision and have potentials for greater productivity, hence are more efficient in agricultural production than older farmers.

The years of farming experience of Onion producers as reflected in table 1, indicates that most of the respondents $41.23 \%$ had between $5-14$ years of farming experience, 39.47\% had between $15-24$ years; $10.53 \%$ had less than 5 years of experience in Onion farming while only $8.77 \%$ had 25 years and above of onion farming experience in the study area. This study therefore reveals that most of the respondents were well experienced in onion farming and as such could manage the risks inherent in Agricultural production activities.

As indicated also, majority of onion producers $(89.5 \%$ were male, with only $10.5 \%$ were females. This implies that men were found to be in active participation in onion production in the study area more than their women counterparts. 
Economic Analysis of Onion Production Along River Komadugu Area of Yobe State,Nigeria.

Table 1. Socio-economic characteristics of onion farmers along river Komadugu area in Yobe State.

\begin{tabular}{lcl}
\hline Variables & Frequency & Percentage \\
\hline Age & 12 & 17.91 \\
$25-34$ & 33 & 49.25 \\
$35-44$ & 20 & 29.85 \\
$45-54$ & 2 & 2.99 \\
$55-64$ & - & - \\
65 and above & & \\
\hline Gender & 63 & 94.03 \\
Male & 4 & 5.9 \\
Female & & \\
\hline Years of experience & 35 & 52.24 \\
Below 5 & 23 & 34.33 \\
$5-14$ & 9 & 13.43 \\
$15-24$ & - & - \\
25 and above & & \\
\hline
\end{tabular}

Source: Field Survey, 2012-2013.

Table 2. Costs and Returns Components for Onion Farming.

\begin{tabular}{lll}
\hline Items & Cost (A /ha) & Percentage \% \\
\hline A. Variable cost & & \\
Material inputs & $45,642.00$ & 29.0 \\
Fertilizer (kg) & $4,357.00$ & 2.8 \\
Insecticides (liters) & $4,941.00$ & 3.1 \\
Herbicides (liters) & $25,777.00$ & 16.4 \\
Fuel (liters) & $20,834.00$ & 13.2 \\
Seeds (kg) & $\mathbf{1 0 1 , 5 5 1 . 0 0}$ & $\mathbf{6 4 . 6}$ \\
Sub-Total (A1) & & \\
Labour inputs & $8,250.00$ & 5.2 \\
Land preparation) & $10,000.00$ & 6.4 \\
Planting & $2,000.00$ & 1.3 \\
Fertilizer application. & $2,500.00$ & 1.6 \\
Herbicide application & $2,500.00$ & 1.6 \\
Insecticide application & $6,250.00$ & 4.0 \\
Weeding (man-hours) & $4,350.00$ & 2.8 \\
Irigation (man-hours) & $14,000.00$ & 8.9 \\
Harvesting\& bagging & $3,700.00$ & 2.4 \\
Transportation & $\mathbf{5 3 , 5 5 0 . 0 0}$ & $\mathbf{3 4 . 1}$ \\
Sub-Total (A2) & & \\
B.Fixed costs & & 1.3 \\
Depreciation of irrigation machine & $2,150.00$ & \\
TOTAL COST (A1+A2+B) & $\mathbf{1 5 7 , 2 5 1 . 0 0}$ & \\
Revenue component & & \\
Average output (kg/ha) & 3929.00 & \\
Price (A/kg) & 65.00 & \\
Total Revenue (A/ha) & $255,385.00$ & \\
Gross income (A/ha) & $100,284.00$ & \\
Net profit (Aha) & $98,134.00$ & \\
Retum on naira & 0.62 & \\
\hline Survey, 2012-2013. & & \\
\hline
\end{tabular}

Source: Field Survey, 2012-2013.

A table 2 show per hectare costs and returns of Onion production in the study area. Which reveals the total cost of production to be $\mathrm{N} 157,251.00$ per hectare. The value of the fixed cost components constituted only $\mathrm{N} 2,150.00$ incurred from depreciated values of farm implements, which indicated the low level of investment on the fixed assets as depicted by the lowest percentage of the total cost of production by onion producers in the study area. The study also reveals that the cost of fertilizer along made up $29.0 \%$, which amounted to N45, 642.00 per hectare. The study futher reveals that $\mathrm{N} 53,550.00$ per hectare was expended on labour which 
constituted the highest amount and it represents $34.1 \%$ of the total cost of production. This could be due to labour intensive nature of the enterprise. Fuel along attained $16.4 \%$ of the variable cost. This study clearly indicated that labour, fuel and fertilizer constituted the largest proportion of the total cost of Onion production in the study area. The result of this survey therefore indicated that the variable cost accounted for $98.7 \%$ of the total cost.

\section{Revenue Components}

The average output per hectare of Onion among the farmers in the study area was found to be 3,929 $\mathrm{kg} / \mathrm{ha}$ and the average price was N65 per kg. The analysis shows that gross revenue of N100, 284.00 was realized, return on every naira invested was found to be 0.62 . Hence, the cost and return analysis indicated that Onion production in the study area was profitable.

Table 3. Estimated regression result derived from Double-log production function in the study area.

\begin{tabular}{lllll}
\hline Variables & Coefficient & Standard error & t-value & Significant level \\
\hline Constant $\left(\mathrm{X}_{0}\right)$ & 2.18 & 0.182 & $3.282^{* *}$ & 0.000 \\
Land size $\left(\mathrm{X}_{1}\right)$ & 0.097 & 0.060 & $2.531^{* *}$ & 0.000 \\
Hired labour $\left(\mathrm{X}_{2}\right)$ & 0.085 & 0.032 & $3.701^{* *}$ & 0.003 \\
Seeds $\left(\mathrm{X}_{3}\right)$ & 0.201 & 0.077 & $2.074^{*}$ & 0.022 \\
Herbicides $\left(\mathrm{X}_{4}\right)$ & 0.234 & 0.116 & $0.938^{\mathrm{NS}}$ & 0.273 \\
Fertilizer $\left(\mathrm{X}_{5}\right)$ & 0.205 & 0.056 & $2.631^{* *}$ & 0.002 \\
Insecticide $\left(\mathrm{X}_{6}\right)$ & 0.126 & 0.146 & $1.111^{\mathrm{NS}}$ & 0.269 \\
& & & & \\
F-value & 58.837 & & & \\
$\mathrm{R}^{2}$-value & 0.832 & & & \\
$\mathrm{R}^{2}$-Adjusted & 0.809 & & & \\
* $^{*} \mathrm{p}<0.01$ & ${ }^{*} \mathrm{p}<0.05$ & $\mathrm{NS}=$ Not Significant &
\end{tabular}

Source: Field Survey, 2012-2013.

In determining the variables influencing the productivity of onion in the study, the analytical procedure employed was production function analysis. This was used to obtain the parameters for the measurement of resource-use efficiency of the onion farmers. Three functional forms were tried and the best fitted model was the double-log function. It recorded a coefficient of determination $\left(\mathrm{R}^{2}\right)$ of 0.832 . The implication of this is that approximately $83 \%$ of the variations in onion output in the study area were explained by the independent variables. The remaining $17 \%$ can be attributed to error in specification and exclusion of other factors from the model. Moreover, fertilizer, land and labour significantly affected the onion output at one percent level; on the other hand, seed affected the output at 5 percent level of significance. Six variables were included in the model; of these four were statistically significant (land, seed, labour and fertilizer). All four had positive coefficients, showing that as their corresponding variable increase, the onion output increases. This result is expected since other variables (insecticide and herbicide) are related to the level of technology of the farmers, and one expects that increased farmer's technology in the use of agrochemicals will increase the yield. The coefficient of insecticide(X6) and Herbicide $\left(\mathrm{X}_{4}\right)$ were positive which agrees with the a priori expectation but does not have significant effect on the output.

Table 4: Estimated marginal physical product (MPP) and marginal value product (MVP).

\begin{tabular}{lcl}
\hline Variables & MPP $(\mathrm{kg} / \mathrm{ha})$ & \multicolumn{1}{c}{ MVP(N/ha } \\
\hline Farm size $\left(\mathrm{X}_{1}\right)$ & 222.60 & $14,469.00$ \\
Hired Labour $\left(\mathrm{X}_{2}\right)$ & 100.90 & $6,558.50$ \\
Seed $\left(\mathrm{X}_{3}\right)$ & 100.99 & $6,564.35$ \\
Herbicide $\left(\mathrm{X}_{4}\right)$ & 15.00 & 950.00 \\
Fertilizer $\left(\mathrm{X}_{5}\right)$ & 70.00 & $4,550.00$ \\
Insecticide $\left(\mathrm{X}_{6}\right)$ & 12.50 & 812.50 \\
\hline
\end{tabular}

Source: Computed from Regression result

Based on the result of values of the marginal physical product(MPP) and marginal value product(MVP) in table 4 , a unit increase in farm size has increased output by $222.60 \mathrm{~kg}$, while revenue would be increased by $\mathrm{N} 14,469.00$ per hectare. As regards to fertilizer applied, a unit of fertilizer applied would result in increased quantity of output by $70.00 \mathrm{~kg}$ and revenue by $\mathrm{N} 4550.00$. Also a unit increased in one man hour of labour would increase yield by $100.90 \mathrm{~kg}$ and revenue by $\mathrm{N} 6,558.50$. Lastly a unit increase in seed, would increase yield by $100.99 \mathrm{~kg}$ and revenue by $\mathrm{N} 6,564.3 \mathrm{~kg}$ per hectare respectively. The marginal value product (MVP) result 
revealed that apart from herbicide and insecticide, which were not significant, other variables used have positive signs, indicating that output could be increased by using more units of inputs.

Table 5: Ratios of marginal value product (MVP) and marginal factor cost (MFC).

\begin{tabular}{lccc}
\hline Variables & MFC(A & MVP $(\mathrm{A} / \mathrm{kg})$ & MVP/MFC=r \\
\hline Farm size $\left(\mathrm{X}_{1}\right)$ & $6,000.00$ & $14,469.00$ & 2.41 \\
Hired Labour $\left(\mathrm{X}_{2}\right)$ & 700.00 & $6,558.50$ & 9.37 \\
Seed $\left(\mathrm{X}_{3}\right)$ & 1000.00 & $6,564.35$ & 6.56 \\
Herbicide $\left(\mathrm{X}_{4}\right)$ & 1800.00 & 950.00 & 0.53 \\
Fertilizer $\left(\mathrm{X}_{5}\right)$ & $2,062.00$ & $4,550.00$ & 2.21 \\
Insecticide $\left(\mathrm{X}_{6}\right)$ & $1,050.00$ & 812.50 & 0.43 \\
\hline
\end{tabular}

Source: Computed from regression result.

The marginal analysis of input utilization was used to determine whether resource used was over utilized, under utilized or efficiently utilized. This was realized by determining the ratios of marginal value product and marginal factor cost. Table 5 results of the analysis reveals that some of the ratios of marginal value product(MVP) and marginal factor cost(MFC) were less than one, with the exception of farm size, labour, seed and fertilizer used; indicating that insecticide and herbicide were under utilized in onion production with efficiency ratios less than one( 0.77 and 0.54$)$, while land size, Hired labour, seed and fertilizer has efficiency ratio greater than one (2.41, 9.37, 6.56 and 2.21), which revealed an over utilization of the available resource.

This indicated that necessary relative Adjustment in marginal value productivities was required for efficient allocation of the resource inputs used.

Table 6: Resource adjustment in marginal Value Product of inputs used.

\begin{tabular}{ll}
\hline Variables & Absolute value of required adjustment \\
\hline Farm size & 58.50 \\
Hired labour & 89.30 \\
Seed & 84.80 \\
Herbicide & 88.70 \\
Fertilizer & 54.80 \\
Insecticide & 29.00 \\
\hline
\end{tabular}

Source: computed from regression results

The result as presented in table 6 revealed that increasing the rate of use of herbicide and insecticide by $89 \%$ and $29 \%$ would increase the level of output, and decreasing the farm size, Hired labour, seeds and Fertilizer by $59 \%, 89 \%, 85 \%$ and $55 \%$ would enhance optimal productivity in the study area.

Table 7: Producer's constraints to onion production

\begin{tabular}{lcl}
\hline Constraints & Frequency* $(\mathrm{n}=114)$ & Percentage* \\
\hline High cost of production inputs. & 86 & 75.44 \\
Lack of storage facilities & 78 & 68.42 \\
Inadequate credit facilities & 63 & 55.26 \\
Limited access to improved seed & 72 & 63.16 \\
Pest and diseases & 82 & 71.93 \\
Lack of effective extension services & 36 & 31.58 \\
Lack of production incentives from govt. & 36 & 43.86 \\
\hline
\end{tabular}

Source: Field Survey, 2010.

\section{*Multiple responses.}

From table 7, it is obvious that the most glaring constraint of onion farmers in the area of study was problems of high cost of production inputs $(75.44 \%)$, this was followed by effect of pest and diseases(71.93\%), then lack of storage facilities(68.42\%), limited access to improve onion seed(63.16\%), also inadequate credit facilities $(55.26 \%)$, Then lack of production incentives from government(43.86\%) and finally lack of affective extension services(31.58\%). High cost of production input which is the predominant constraint of the farmers in the study area was certainly the problem that is outside the farmers control and can lead to low productivity. Also, the problem of pest and diseases can affect the productivity of the farmers negatively. The problem of lack of storage facilities has a great influence in the marketing of farmer's products in the study area, since onion can easily be spoiled if care is not given and finally affect the market value of the products. The 
problem of ineffective extension services and that of lack of production incentives from government can also have negative effects on productivity of onion farming even though, it tend to be low interms of the percentage of the respondents; $(31.58 \%)$ and $(43.86 \%)$ respectively.

\section{Conclusion}

Onion farming in this study also indicates that farmers were faced with constraints in spites of these, they were able to make profit of $\mathrm{N98}, 134.00 / \mathrm{ha}$ as net farm income. The study also found that land size, labour, seed and fertilizer were over utilized for onion production with efficiency ratios greater than one $(2.41,9.37$, 6.56 and 2.21) while, insecticide and herbicide were under utilized in onion production with efficiency ratios of less than one ( 0.77 and 0.54$)$. The study identified major constraints in onion production to include high cost of production inputs, pest and disease, inadequate storage facilities and limited access to improved seed.

\section{Recommendations}

- Farmers should form cooperative unit for the purpose of self-help in terms of input acquisition and output marketing.

- Farmers need to be taught new storage technology so as to be able to reduce losses.

- Extension agents should have a close contact with the farmers during the production season so as to demonstrate to them the proper ways of input application.

\section{References}

[1]. Ali, M. and Chaudhy, M.A (1990) "Inter-regional farm efficiency in Pakistan's Punjab: A Frontier production function study" Journal of Agricultural Economics.17(4):62-74

[2]. Amaza, P.S. (2000) ''Resource-use Efficiency in food crop production in Gombe state Nigeria'. A Ph.d Thesis (unpublished). Department of Agricultural Economics, University of Ibadan Nigeria.

[3]. Nasiru, M.I.(2000) "Economic Analysis of tomato Marketing, A case study of Kano Metropolis, Kano State" M.sc Thesis(unpublished)Department of Agricultural Economics, Bayero University Kano, Nigeria,pp.34-46.

[4]. National Population Commission-NPC- (2006) "Provisional Census figure of Yobe State: NPC/FGN, Abuja, P.32.

[5]. NEAZDP,(1999).North East Arid Zone Development Programme,Borno and Yobe States." "Annual program me evaluation report" $38 \mathrm{p}$, series No.8.

[6]. Ogunjobi, O.P.(1999) "Efficiency of small holder cocoa farmer in Ondo State" Journal of Social Science 17(2): 62-68.

[7]. Olayide, S.O. and Heady, E.O.(1982): Introduction to Agricultural Production Economics: University of Ibadan Press,pp.23-31.

[8]. Peter, S.F.(1996) "Onion production in the tropics" American Journal of Agricultural Economics 63(3): 321-328

[9]. Purse glove, J.W.(2000) Tropical Crop Monocotyledons. Longman Group Limited, 407p.

[10]. Salomon, S.T (2010)"The importance of efficient use in the adoption Technology" A micro Panel data analysis, Journal o $\mathrm{f}$ production Analysis.34(2):37-40

[11]. USAID, Trade Catalyst Report (2011)"Producing Ready for Retail Onions in west Africa,p.45.

[12]. Warreb, T.D. (1975). Onion Allium cepa L. and Allium cepa L. var. Aggregatun production in Ibadan, South West Nigeria; prospects and limitations. Paper presented at the $11^{\text {th }}$ Annual conference of Horticultural society of Nigeria. Ogun State University, Agolwoye, 1-4 April, 1974.

[13]. Wright, V.I (1992)"Socio-economic considerations in Onion production and handling in the Philippines: Opportunity for technology transfer. Onions News letter for the tropics.5:10-15. 